\title{
Biological effect of zirconium dioxide-based nanoparticles
}

\author{
O. V. Almjasheva ${ }^{1,2}$, A. V. Garabadzhiu ${ }^{3}$, Yu. V. Kozina ${ }^{3}$, L.F. Litvinchuk ${ }^{4}$, V.P. Dobritsa ${ }^{4}$ \\ ${ }^{1}$ St. Petersburg Electrotechnical University "LETI", ul. Professora Popova 5, 197376 St. Petersburg, Russia \\ ${ }^{2}$ Ioffe Institute, Politekhnicheskaya st., 26, St. Petersburg, 194021, Russia \\ ${ }^{3}$ St. Petersburg State Technological Institute (Technical university) \\ Moskovsky prospect 26, 190013 St. Petersburg, Russia \\ ${ }^{4}$ State Research Institute of Highly Pure Biopreparations of the Federal Medical Biological Agency FMB, \\ Pudozhskaya ul. 7, 197110 St. Petersburg, Russia \\ almjasheva@mail.ru
}

PACS 61.46.+w, 42.62

DOI 10.17586/2220-8054-2017-8-3-391-396

\begin{abstract}
This work demonstrates the positive effects of zirconium dioxide nanoparticles on cells in vitro. This is supported by the absence of toxicity, stimulation of metabolic and proliferative activity. The nanoparticles of solid solution of europium oxide in europium dioxide do not exhibit an explicit biological effect. The potentially successful application of zirconium dioxide-based nanoparticles in pharmacology has been demonstrated.
\end{abstract}

Keywords: zirconium dioxide, europium oxide, nanoparticles, toxicity, metabolic activity, proliferative activity.

Received: 7 March 2017

Revised: 15 March 2017

\section{Introduction}

Systematic studies of biological effects of nanoparticles of varying compositions, morphologies and dimensions have been performed by many authors [1-4]. This is due to both their potential medical application of nanoparticles [5-11] and danger for humans [12-15]. The promising future of biomedical application and the potential danger of nanoparticles are to a considerable extent predicated by their ability to penetrate through cell and intercellular membranes and, therefore, spread throughout the organism.

Previous research [16-22] has demonstrated the promising results for the application of nanoparticles of some metal dioxides and of solid solutions, which are composed so that they will have utility in biomedical applications. The additives, which provide certain functional properties to nanostructured materials, in particular, luminescent properties, are often used in the aforementioned nanoparticles as an admixture component. The luminescent properties of those nanoparticles that are intended for biomedical application can be useful when analysing the distribution of nanoparticles within living organisms.

One promising method for obtaining oxide nanoparticles is hydrothermal processing of the respective hydroxides. A significant advantage of hydrothermal synthesis, as compared to other methods, is that it makes it possible to obtain in some cases, as was shown in [23-27], almost completely non-agglomerated nanoparticles, which have a narrow size distribution range. Such properties of the nanopowders, which are formed under hydrothermal conditions, are the result of a fast nucleation process, as was shown in [28,29].

It is worth noting that though there are several studies [16-22] dedicated to the biological effects of the nanoparticles, which are based on metal dioxides such as $\mathrm{TiO}_{2}, \mathrm{HfO}_{2}, \mathrm{CeO}_{2}$, and solid solutions containing them, there is considerably less information about the biological effect of zirconium dioxide-based nanoparticles [30-32]. However, since zirconium dioxide based nanopowders, solid solutions, nanocomposites and other $\mathrm{ZrO}_{2}$-containing nanomaterials, have become widely spread in scientific research and technological applications [33-37], studying their biological effect is important.

The reasons listed above provide the motivation for us to study the impact that $\mathrm{ZrO}_{2}$-based nanoparticles and solid solutions such as the luminescent $\mathrm{ZrO}_{2}\left(\mathrm{Eu}_{2} \mathrm{O}_{3}\right)$ have on biological objects.

\section{Experimental methods}

\subsection{Synthesis of nanoparticles}

Zirconium dioxide-based nanoparticles were obtained through hydrothermal processing of preliminarily coprecipitated zirconium and europium hydroxides at $225{ }^{\circ} \mathrm{C}$ and under a pressure of $10 \mathrm{MPa}$ during $2 \mathrm{~h}$ in accordance with the methods described in the work [23]. 
The structural state and the size of the crystallites of the nanoparticles obtained were determined on the basis of X-ray diffractometry of the samples (diffractometer DRON-3, $\mathrm{CuK} \alpha$-radiation). The calculation of the ratio of monoclinic and cubic $\mathrm{ZrO}_{2}$ modifications was performed using the formula given in [23]. The size of crystallites was calculated based on the data, which refers to the broadening of X-ray diffraction lines, using Scherrer's formula.

The size of particles was analyzed on the basis of transmission electron microscopy (microscope EM-125 with $U a c c=75 \mathrm{kV})$.

\subsection{Biological effect of nanoparticles (materials and methods)}

The study of biological characteristics of $\mathrm{ZrO}_{2}$ and $\mathrm{ZrO}_{2}\left(\mathrm{Eu}_{2} \mathrm{O}_{3} 1\right.$ mol.\%) nanoparticles was performed using preparations in the form of suspensions of nanoparticles of the said composition. The preparations under study were represented by the suspensions of nanoparticles of two types: highly diluted suspensions of nanocrystals and concentrated suspensions. Testing was carried out on the monolayer of the cell line L-41 (bone marrow cells from a leukemia patient) for all four types of preparations using a wide range of concentrations with nearly a hundred-fold variance. A full description of the procedures for cytotoxicity and biological activity analyses of $\mathrm{ZrO}_{2}$ and $\mathrm{ZrO}_{2}\left(\mathrm{Eu}_{2} \mathrm{O}_{3}\right)$ nanoparticles is given below.

The dispersions of $\mathrm{ZrO}_{2}$ and $\mathrm{ZrO}_{2}\left(1 \mathrm{~mol} . \% \mathrm{Eu}_{2} \mathrm{O}_{3}\right)$ nanoparticles were studied, which were taken in the form of two fractions - supernatant fluid and sediment. All the fractions were studied separately. The degree of dispersion dilution with water is given in Table 1. In total, 7 compositions of supernatant fluid and 6 compositions of sediment were studied. $\mathrm{ZrO}_{2}$ sediment was re-suspended in $3.0 \mathrm{ml}$ of supernatant fluid. $\mathrm{ZrO}_{2}\left(1 \mathrm{~mol}^{\circ} \% \mathrm{EuO}_{3}\right)$ sediment was re-suspended in $2.0 \mathrm{ml}$.

TABLE 1. Dilution of the fractions of sediment and supernatant dispersion of $\mathrm{ZrO}_{2}$ and $\mathrm{ZrO}_{2}\left(\mathrm{Eu}_{2} \mathrm{O}_{3}\right)$

\begin{tabular}{|c|c|c|c|c|c|c|}
\hline \multirow{5}{*}{$\stackrel{\infty}{\stackrel{\infty}{x}}$} & & \multicolumn{2}{|c|}{ Supernatant fraction } & \multirow[b]{2}{*}{ No } & \multicolumn{2}{|c|}{ Sediment } \\
\hline & No & $\begin{array}{l}\text { Volume of } \\
\text { culture } \\
\text { medium, mcl }\end{array}$ & $\begin{array}{c}\text { Volume of } \\
\text { studied } \\
\text { compounds, mcl }\end{array}$ & & $\begin{array}{l}\text { Volume of } \\
\text { culture } \\
\text { medium, mcl }\end{array}$ & $\begin{array}{c}\text { Volume of } \\
\text { studied } \\
\text { compounds, } \mathrm{mcl}\end{array}$ \\
\hline & 1 & 1.000 & 300 & 8 & 1.000 & 200 \\
\hline & 2 & 1.000 & 200 & 9 & 1.000 & 100 \\
\hline & 3 & 1.000 & 50 & 10 & 1.000 & 25 \\
\hline \multirow{4}{*}{ : } & 4 & 1.000 & $\begin{array}{c}1.000 \\
\text { (dilution 3) }\end{array}$ & 11 & 1.000 & $\begin{array}{c}1.000 \\
\text { (dilution 9) }\end{array}$ \\
\hline & 5 & 1.000 & $\begin{array}{c}1.000 \\
\text { (dilution 4) }\end{array}$ & 12 & 1,000 & $\begin{array}{c}1.000 \\
\text { (dilution 10) }\end{array}$ \\
\hline & 6 & 1.000 & $\begin{array}{c}1.000 \\
\text { (dilution 5) }\end{array}$ & 13 & 1.000 & $\begin{array}{c}1.000 \\
\text { (dilution 11) }\end{array}$ \\
\hline & 7 & 1.000 & $\begin{array}{c}1.000 \\
\text { (dilution 6) }\end{array}$ & & & \\
\hline
\end{tabular}

Constant cell line L-41 was used as the cell model. The line was cultivated in MEM (MEM - Minimum Essential Medium) with addition of $7 \%$ of ABS (Adult Bovine Serum for cell culture) (of Biolot company) (ABS = Adult Bovine Serum for cell culture 'Biolot') and gentamicin (100 U/ml).

The following characteristics were studied: cytotoxicity, proliferative activity and metabolic activity, determined by spectrophotometric analysis by means of MTT assay.

To determine cytotoxicity in lifetime condition, the cells were inoculated on 96-well plastic plates. The changes were registered visually during the period of 1-10 days by means of inverted microscope (Leitz, Germany). To prepare cytological preparations, the cells were inoculated on coverslips, then fixed with methanol (10 min) and stained in accordance with Romanovsky-Giemsa method. The substances under study were applied on the intraday monolayer of the cell line L-41 in the proper concentrations.

To determine proliferative activity, the cells, taken in the concentration 50,000 per ml, were inoculated into plastic flasks of $30 \mathrm{ml}$ in volume where the studied substances had already been introduced into the culture medium. The quantity of control flasks was equal to 5; the quantity of flasks per each tested concentration was 3 . The cells, in order for them to be counted, were removed on the fourth day of cultivation. The effect of the studied 
compounds on cell proliferation was determined for the concentrations 6 and 7 (Table 1). Proliferation index was calculated as the ratio of the yield of experimental cells to the yield of control cells.

In order to study the metabolic activity, the cells were inoculated on 96-well plates and the fractions under study were introduced on the monolayer in supporting medium MEM without serum after a day.

The registration with the use of MTT-assay was performed at different points of cultivation timeline in the presence of fractions of the studied compounds.

\section{Results and discussion}

The nanopowders that are based on $\mathrm{ZrO}_{2}$ and $\mathrm{ZrO}_{2}\left(1 \mathrm{~mol} \% \mathrm{Eu}_{2} \mathrm{O}_{3}\right)$ were obtained under hydrothermal conditions. The analysis of the structure condition showed that the obtained nanocrystals are predominantly represented by tetragonal modification of zirconium dioxide $\left(t-\mathrm{ZrO}_{2}\right)$. In zirconium dioxide-based samples, the ratio of tetragonal modification and monoclinic modification of zirconium dioxide $\left(m-\mathrm{ZrO}_{2}\right)$ constitutes 80:20 mol.\% (Fig. 1). Such ratio of structural types for zirconium dioxide nanoparticles, being formed under the conditions of hydrothermal processing, had also been noted earlier [23,28,29,38]. The introduction of $1 \mathrm{~mol}^{\circ} \mathrm{Eu}_{2} \mathrm{O}_{3}$ under hydrothermal conditions leads to the formation of zirconium dioxide-based nanocrystals of only tetragonal modification (Fig. 1).

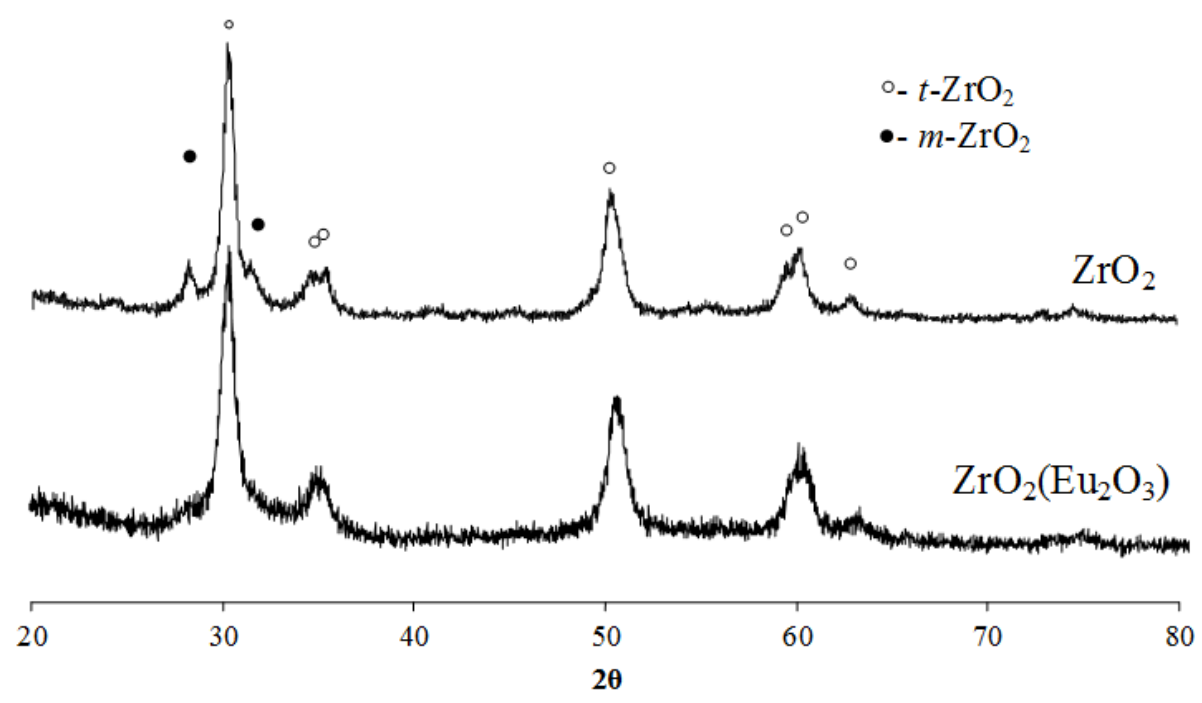

FIG. 1. X-ray diffractogram of $\mathrm{ZrO}_{2}$ and $\mathrm{ZrO}_{2}\left(1 \mathrm{~mol} . \% \mathrm{Eu}_{2} \mathrm{O}_{3}\right)$ nanopowders

The average size of $\mathrm{ZrO}_{2}$ crystals having monoclinic and tetragonal modification, determined using the Xray diffraction line broadening values, were 15 and $22 \mathrm{~nm}$, respectively. Analysis of the X-ray diffraction lines broadening for $\mathrm{ZrO}_{2}\left(1 \mathrm{~mol} \% \mathrm{Eu}_{2} \mathrm{O}_{3}\right)$ sample, showed that the average size of $\mathrm{ZrO}_{2}\left(\mathrm{Eu}_{2} \mathrm{O}_{3}\right)$ crystals was $10 \mathrm{~nm}$. Analysis of the nanopowders using transmission electron microscopy revealed that the average size of particles, of both $\mathrm{ZrO}_{2}$, and $\mathrm{ZrO}_{2}\left(1 \mathrm{~mol} \% \mathrm{Eu}_{2} \mathrm{O}_{3}\right)$, in general ranged from 10 to $15 \mathrm{~nm}$ with quite a narrow range of distribution of particles by size (Fig. 2). That is the sizes of particles, within the error of methods, coincide with the size of crystals.

The studies of cytotoxicity (lifetime observation) undertaken within 10 days of culturing (5 experiments) showed the absence of explicit destructive and degenerative processes, both in the structure of confluent monolayer, and in the cells themselves, as well as under the influence of higher concentrations (Table 1, positions 1, 2, $8,9)$. No apparent toxicosis, cell destruction and polymorphism were observed on cytological preparations in the concentrations 2 and 3 (supernatant fraction) and 9, 10 (sediment), i.e. at the highest concentrations. The presence of a clearly visible considerable quantity for the solid-phase fraction of the preparations under study on the cell monolayer was noted at concentrations 9 and 10. Nevertheless, in this case, no significant changes were observed in the main morphofunctional characteristics of the cells.

To evaluate the proliferative activity of the cells L-41, which were cultured in the presence of the studied supernatant fractions based on $\mathrm{ZrO}_{2}$ nanocrystals and supernatant based on $\mathrm{ZrO}_{2}\left(\mathrm{Eu}_{2} \mathrm{O}_{3}\right)$ nanocrystals, the index of proliferation was determined. The concentrations 6 and 7 (Table 2) were used. 

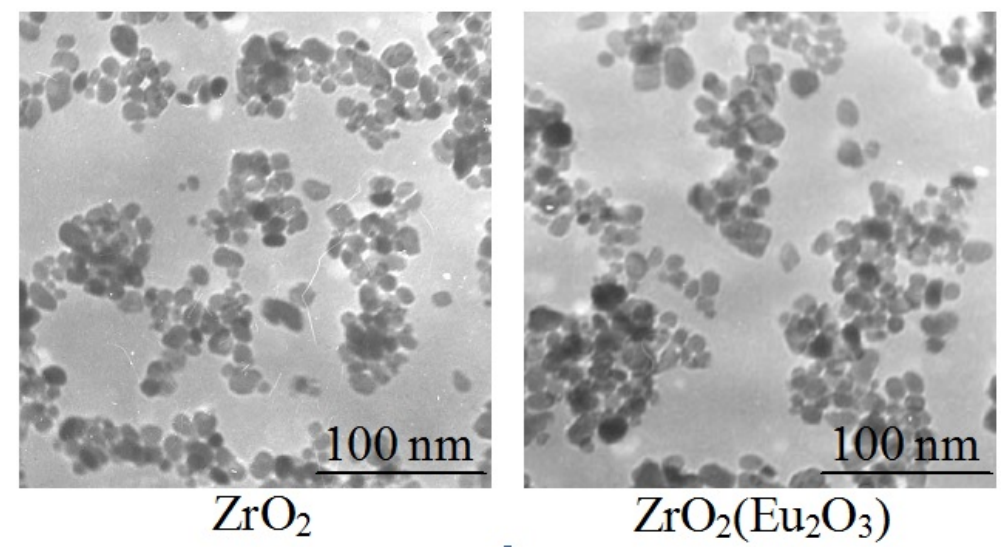

FIG. 2. Microphotos of $\mathrm{ZrO}_{2}$ and $\mathrm{ZrO}_{2}\left(1 \mathrm{~mol} . \% \mathrm{Eu}_{2} \mathrm{O}_{3}\right)$ nanopowders

TABLE 2. Results of determination of proliferative activity of nanoparticles

\begin{tabular}{|c|c|c|c|}
\hline \multicolumn{2}{|c|}{$\mathrm{ZrO}_{2}$ nanoparticles } & \multicolumn{2}{c|}{$\mathrm{ZrO}_{2}\left(\mathrm{Eu}_{2} \mathrm{O}_{3}\right)$ nanoparticles } \\
\hline Substance concentrations & Proliferation index & Substance concentrations & Proliferation index \\
\hline 6 & 1.7 & 6 & 1.1 \\
\hline 7 & 1.26 & 7 & 0.95 \\
\hline Control & 1 & Control & 1 \\
\hline
\end{tabular}

As it follows from the data presented in Table 2, $\mathrm{ZrO}_{2}$ nanoparticles render a stimulating influence on the proliferative activity of cells, in small $(1,000: 6.25,1,000: 3.12)$ concentrations. The values of Proliferation index applicable to the samples that are based on the solid solution of $\mathrm{ZrO}_{2}\left(\mathrm{Eu}_{2} \mathrm{O}_{3}\right)$ turned out to be comparable with the control values. Such difference can be attributed to the fact that a considerable portion of the europium oxide in $\mathrm{ZrO}_{2}\left(\mathrm{Eu}_{2} \mathrm{O}_{3}\right)$ nanoparticles can be concentrated on the surface of the nanoparticles, thus forming the structure of 'core-shell' type. The possibility for such structure to appear can be traced in the outcomes of the works [39], which show that the structures of 'core-shell' type are formed when a synthesis is taking place, under analogous conditions, of the nanoparticles, which are based on the solid solutions $\mathrm{ZrO}_{2}\left(\mathrm{Y}_{2} \mathrm{O}_{3}\right), \mathrm{ZrO}_{2}\left(\mathrm{Gd}_{2} \mathrm{O}_{3}\right)$ that are similar in chemical nature to $\mathrm{ZrO}_{2}\left(\mathrm{Eu}_{2} \mathrm{O}_{3}\right)$. Further confirmation was given by the results of the work [38], dedicated to the analysis of luminescent properties of $\mathrm{ZrO}_{2}\left(\mathrm{Eu}_{2} \mathrm{O}_{3}\right)$, in which a conclusion is drawn about the partial localization of europium oxide on the surface of nanoparticles. In connection with the obtained data, it can be concluded that it is the surface molecules of zirconium dioxide that possess proliferative activity, and the surface, enriched with europium oxide is biologically inert in this respect.

Evaluation of metabolic activity was accomplished using the MTT assay (spectrophotometric analysis), which was carried out in 4 experiments on 96-well plates. The analysis of all the data obtained using MTT assay for each of 4 fractions of the studied samples showed that all the studied compositions did not inhibit the metabolic activity of L-41 cells over a wide range of concentrations $(1,000: 300-1,000: 3.12)$, i.e. at the concentrations of disperse phase, which differ from each other nearly by 100-fold. The MTT assay, which was performed on the third day of cultivation of L-41 cells with each of 4 newly obtained fractions, showed that there were considerable stimulating properties for these fractions, especially of those taken in smaller concentrations. Thus, as it follows from the data of MTT assay, all the studied compositions not only do not inhibit the metabolic activity of L-41 cells, but, if taken in small concentrations, increase it 1.4-1.6 fold. In the course of storage of initial fractions these properties were lost, which may be explained by the change of the surface condition of nanoparticles with time and impairment of the fraction's sterility.

As a result of the cytotoxicity analysis for the studied compositions, the absence of the expressed cytotoxicity both in the structure of the confluent monolayer and in the cells themselves, as well as under the influence of large concentrations of nanoparticles (ratio of culture medium and the studied fraction constitutes 10:3), was determined. No changes of basic morphofunctional characteristics of cells were observed, even in the case of the presence of considerable quantity of disperse phase based on $\mathrm{ZrO}_{2}$ and $\mathrm{ZrO}_{2}\left(\mathrm{Eu}_{2} \mathrm{O}_{3}\right)$ nanoparticles on the cell monolayer. 
Thus, in order to generalize all the data obtained, it is possible to make a conclusion about the positive character of the influence of $\mathrm{ZrO}_{2}$ and $\mathrm{ZrO}_{2}\left(1 \mathrm{~mol} \% \mathrm{Eu}_{2} \mathrm{O}_{3}\right)$ nanoparticles on cells in vitro. This is confirmed by the absence of toxicity and by the stimulation of metabolic and proliferative activity. The performed studies show that $\mathrm{ZrO}_{2}$ and $\mathrm{ZrO}_{2}\left(\mathrm{Eu}_{2} \mathrm{O}_{3}\right)$ nanoparticles have promising futures as the objects of further study with regard to their biological properties along with further possible application in pharmacology.

\section{Acknowledgements}

The authors express their gratitude to V. V. Gusarov for the attention he paid to the work and for his help in the interpretation of the results.

The work has been performed with the financial support offered by Russian Science Foundation (Project No. 16-13-10252).

\section{References}

[1] Tretyakov Yu.D. Development of inorganic chemistry as a fundamental for the design of new generations of functional materials. Russ. Chem. Rev., 2004, 73 (9), P. 831-846.

[2] Tretyakov Yu.D., Lukashin A.V., Eliseev A.A. Synthesis of functional nanocomposites based on solid-phase nanoreactors. Russ. Chem. Rev., 2004, 73 (9), P. 899-921.

[3] Maskos M., Stauber R.H. Characterization of nanoparticles in biological environments. Comprehensive Biomaterials, 2011 , 3, P. 329-339.

[4] Löwa N., Seidel M., Radon P., Wiekhorst F. Magnetic nanoparticles in different biological environments analyzed by magnetic particle spectroscopy. Journal of Magnetism and Magnetic Materials, 2017, 427, P. 133-138.

[5] Mirzaei H., Darroudi M. Zinc oxide nanoparticles: Biological synthesis and biomedical applications. Ceramics International, 2017, 43 (1B), P. 907-914.

[6] Hofmann-Amtenbrink M., Grainger D.W., Hofmann H. Nanoparticles in medicine: Current challenges facing inorganic nanoparticle toxicity assessments and standardizations. Nanomedicine: Nanotechnology, Biology and Medicine, 2015,11 (7), P. 1689-1694.

[7] Zarschler K., Rocks L., et al. Ultrasmall inorganic nanoparticles: State-of-the-art and perspectives for biomedical applications. Nanomedicine: Nanotechnology, Biology, and Medicine, 2016, 12 (6), P. 1663-1701.

[8] Duchênea D., Gref R. Small is beautiful: Surprising nanoparticles. International Journal of Pharmaceutics, 2016,502 (1-2), P. $219-231$.

[9] Zeinali Sehrig F., Majidi S., et al. Magnetic nanoparticles as potential candidates for biomedical and biological applications. Artif Cells Nanomed Biotechnol, 2016, 44 (3), P. 918-927.

[10] Pombo Garcia K., Zarschler K., et al. Zwitterionic-coated "stealth" nanoparticles for biomedical applications: recent advances in countering biomolecular corona formation and uptake by the mononuclear phagocyte system. Small, 2014, 10 (13), P. $2516-2529$.

[11] Blanco-Andujar C., Tung L.D., Thanh N.T.K. Synthesis of nanoparticles for biomedical applications. Annu. Rep. Prog. Chem., Sect. A: Inorg. Chem., 2010, 106, P. 553-556.

[12] Gu L., Fang R.H., Sailor M.J., Park J.-H. In vivo clearance and toxicity of monodisperse iron oxide nanocrystals. ACS Nano, 2012, 6 (6), P. 4947-4954.

[13] Balmuri S.R., Selvaraj U., et al. Effect of surfactant in mitigating cadmium oxide nanoparticle toxicity: Implications for mitigating cadmium toxicity in environment. Environmental Research, 2017, 152, P. 141-149.

[14] Jośko I., Oleszczuk P., Skwarek E. Toxicity of combined mixtures of nanoparticles to plants. Journal of Hazardous Materials, 2017, 331, P. 200-209.

[15] Friehs E., AlSalka Y., et.al. Toxicity, phototoxicity and biocidal activity of nanoparticles employed in photocatalysis. Journal of Photochemistry and Photobiology C: Photochemistry Reviews, 2016, 29, P. 1-28.

[16] Karunakaran G., Suriyaprabha R., et al. Screening of in vitro cytotoxicity, antioxidant potential and bioactivity of nano- and micro-ZrO 2 and $-\mathrm{TiO}_{2}$ particles. Ecot. Environ. Safe., 2013, 93, P. 191-197.

[17] Venkatachalam J., Ganesan S., Aruna P. Synthesis and Characterization of Europium Doped Hafnium Oxide Nanoparticles by Precipitation Method. Int. J. Chem. Tech. Res., 2015, 8 (3), P. 1131-1138.

[18] Jayaraman V., Bhavesh G., et al. Synthesis and characterization of hafnium oxide nanoparticles for bio-safety. Mater. Express, 2014, 4 (5), P. $375-383$.

[19] Jayakumar G., Irudayaraj A.A., Raj A.D., Anusuya M. Investigation on the preparation and properties of nanostructured cerium oxide. Nanosystems: Physics, Chemistry, Mathematics, 2016, 7 (4), P. 728-731.

[20] Shcherbakov A.B., Zholobak N.M., Spivak N.Ya., Ivanov V.K. Advances and prospects of using nanocrystalline ceria in cancer theranostics. Russian Journal of Inorganic Chemistry, 2014,59 (13), P. 1556-1575.

[21] Shcherbakov A.B., Zholobak N.M., Spivak N.Ya., Ivanov V.K. Advances and prospects of using nanocrystalline ceria in prolongation of lifespan and healthy aging. Russian Journal of Inorganic Chemistry, 2015, 60 (13), P. 1595-1625.

[22] Zholobak N.M., Shcherbakov A.B., et al. Panthenol-stabilized cerium dioxide nanoparticles for cosmeceutic formulations against ROSinduced and UV-induced damage. Russian Journal of Inorganic Chemistry, 2015, 60 (13), P. 1595-1625.

[23] Pozhidaeva O.V., Korytkova E.N., Drozdova I.A., Gusarov V.V. Phase state and particle size of ultradispersed zirconium dioxide as influenced by condition of hydrothermal synthesis. Russian Journal of General Chemistry, 1999, 69 (8), P. 1219-1222.

[24] Almjasheva O.V. Formation and structural transformations of nanoparticles in the $\mathrm{TiO}_{2}-\mathrm{H}_{2} \mathrm{O}$ system. Nanosystems: Physics, Chemistry, Mathematics, 2016, 7 (6), P. 1031-1049.

[25] Vasilevskay A.K., Almjasheva O.V., Gusarov V.V. Peculiarities of structural transformations in zirconia nanocrystals. Journal of Nanoparticle Research, 2016, 18, P. 188.

[26] Yan L., Yu R., Chen J., Xing X. Template-free hydrothermal synthesis of $\mathrm{CeO}_{2}$ nano-octahedrons and nanorods: investigation of the morphology evolution. Crystal Growth \& Design, 2008, 8 (5), P. 1474-1476. 
[27] Qi J., Zhou X. Formation of tetragonal and monoclinic- $\mathrm{HfO}_{2}$ nanoparticles in the oil/water interface. Colloids and Surfaces A: Physicochemical and Engineering Aspects, 2015, 487, P. 26-34.

[28] Almjasheva O.V., Denisova T.A. Water state in nanocrystals of zirconium dioxide prepared under hydrothermal conditions and its influence on structural transformations. Russian Journal of General Chemistry, 2017, 87 (1), P. 1-7. (doi: 10.1134/S1070363217010017)

[29] Sharikov F.Yu., Almjasheva O.V., Gusarov V.V. Thermal analysis of formation of $\mathrm{ZrO}_{2}$ nanoparticles under hydrothermal conditions. Russian Journal of Inorganic Chemistry, 2006, 51 (10), P. 1538-1542.

[30] Gusarov V.V., Almyasheva O.V., et al. Investigation of an influence of cytotoxicity of zirconium oxide $\left(\mathrm{ZrO}_{2}\right)$ and a solid solution $\left(\mathrm{Zr}_{0.98} \mathrm{Eu}_{0.02} \mathrm{O}_{1.98}\right)$ on the basis there of, which has nanocrystal state on L-41 cell line. International workshop on nanobiotechnologies, 27-29 November 2006, Saint-Petersburg, 2006, P. 77.

[31] Quan R., Tang Y., et al. Difference of adherence, proliferation and osteogenesis of mesenchymal stem cells cultured on different $\mathrm{HA}_{2} \mathrm{ZrO}_{2}$ composites. Chinese Journal of Traumatology, 2012, 15 (3), P. 131-139.

[32] Abd El-Ghany O.S., Sherief A.H. Zirconia based ceramics, some clinical and biological aspects: Review. Future Dental Journal, 2016, 2 (2), P. 55-64.

[33] Fakhri A., Behrouz S., et al. Synthesis and characterization of $\mathrm{ZrO}_{2}$ and carbon-doped $\mathrm{ZrO}_{2}$ nanoparticles for photocatalytic application. Journal of Molecular Liquids, 2016, 216, P. 342-346.

[34] Ao H., Liu X., et al. Preparation of scandia stabilized zirconia powder using microwave-hydrothermal method. Journal of Rare Earths, 2015,33 (7), P. 746-751.

[35] Yudin V.E., Otaigbe J.U., et al. Effects of nanofiller morphology and aspect ratio on the rheo-mechanical properties of polimide nanocomposites. Express Polymer Letters, 2008, 2 (7), P. 485-493.

[36] Almjasheva O.V., Postnov A.Yu., Maltseva N.V., Vlasov E.A. Thermostable catalysts for oxidation of hydrogen based on $\mathrm{ZrO}_{2}-\mathrm{Al}_{2} \mathrm{O}_{3}$ nanocomposite. Nanosystems: Physics, Chemistry, Mathematics, 2012, 3 (6), P. 75-82.

[37] Khoshsima S., Yilmaz B., Tezcaner A., Evis Z. Structural, mechanical and biological properties of hydroxyapatite-zirconia-lanthanum oxide composites. Ceramics International, 2016, 42 (14), P. 15773-15779.

[38] Bugrov A.N., Rodionov I.A., et al. Photocatalytic activity and luminescent properties of Y, Eu, Tb, Sm and Er-doped ZrO 2 nanoparticles obtained by hydrothermal method. Int. J. Nanotechnology, 2016, 13 (1-3), P. 147-157.

[39] Smirnov A.V., Fedorov B.A., et al. Core-shell nanoparticles forming in the $\mathrm{ZrO}_{2}-\mathrm{Gd}_{2} \mathrm{O}_{3}-\mathrm{H}_{2} \mathrm{O}$ system under hydrothermal conditions. Doklady Physical Chemistry, 2014, 456 (1), P. 71-73. 